\title{
Uji In Vitro Daya Anti Bakterial Virgin Coconut Oil (VCO) pada Salmonella typhi
}

\author{
Nita Noriko ${ }^{1}$, Agus Masduki ${ }^{1,2}$, Rahmat Azhari $^{1}$, Grariani Nufadianti $^{1 *}$ \\ ${ }^{1}$ Program Studi Biolgi, Fakultas Sains danTeknologi, \\ Universitas Al Azhar Indonesia, Jl. Sisingamangaraja, Jakarta 12110 \\ ${ }^{2}$ Badan Pengkajian dan Penerapan Teknologi (BPPT)
}

Penulis untuk korespondensi/E-mail: grariani@gmail.com

\begin{abstract}
Abstrak - Salah satu penyakit yang timbul akibat infeksi bakteri adalah demam tifoid atau typhoid fever. Typhoid disebabkan oleh infeksi bakteri Salmonella typhi. Infeksi akibat bakteri ini dapat diobati dengan menggunakan antibiotik sintetik ataupun alami. Antibiotik sintetik lebih populer dibandingkan alami namun, antibiotik sintesis dapat membunuh bakteri menguntungkan yang ada dalam tubuh. Virgin Coconut Oil (VCO) telah dikenal atas manfaatnya bagi kesehatan manusia, salah satunya adalah daya antibakterinya. Penelitian ini bertujuan untuk mengetahui daya antibakteri VCO terhadap bakteri Salmonella typhi, sehingga diharapkan VCO dapat menjadi fitofarmaka untuk mengobati penyakit tipus. Daya antibakteri VCO diuji dengan metode uji Kirby-bauer dan pour plate. Hasil penelitian menunjukkan adanya daya hambat VCO terhadap pertumbuhan $S$. typhi secara invitro. Hal ini dibuktikan oleh adanya zona hambat dengan metode Kirby-bauer dan penghambatan pertumbuhan $S$. typhi dengan metode pour plate. Hasil tersebut menunjukkan bahwa VCO mempunyai potensi sebagai antibakteri pada $S$. typhi.
\end{abstract}

Abstract - Thyphoid fever is endemic disease in Indonesia, attacking at all ages, and this disease can cause death. Typhoid is caused by infection of bacterium Salmonella typhi. This bacterial infection can be treated using natural or synthetic antibiotics. Synthetic antibiotics are more popular than natural one, however, the synthetic antibiotics can kill the beneficial bacteria in the body Virgin Coconut Oil (VCO) has been popular for its benefits for human health, one of them is its antibacterial activity. This study aims to determine the antibacterial activity of the VCO on the bacteria Salmonella typhi. It's expected that VCO can be a phytopharmaca to treat typhoid. This research used Kirby-Bauer test and pour plate as a method. Result shows that VCO has inhibition zones against $S$. typhi that was confirmed by the Kirby-Bauer test which is the zone of inhibition and inhibition of growth of $S$. typhi in the pour plate. Thus, VCO has a potential as antibacterial agent against $S$. typhi.

Keywords - Virgin Coconut Oil, antibacterial activity, Salmonella typhi, inhibition zone

\section{PENDAHULUAN}

$\mathrm{S}$ alah satu penyakit yang timbul akibat infeksi bakteri adalah demam tifoid atau typhoid fever. Typhoid disebabkan oleh infeksi bakteri Salmonella typhi [1]. Bakteri yang termasuk dalam golongan gram negatif ini, menyerang usus halus dan menyebabkan penyakit endemik di Indonesia [2].

Penyakit ini menyerang segala usia, tetapi paling sering menyerang anak-anak [2]. Berdasarkan data Dinas Kesehatan Kota Semarang demam tifoid termasuk dalam 10 besar penyakit yang diderita warga kota semarang. Hal tersebut terlihat dari jumlah penderita tifoid di Semarang, pada tahun 2009 tercatat 7507 penderita yang terdaftar di rumah sakit sedangkan pada tahun 2010 terdapat 2516 penderita [3] [4].

Berdasarkan laporan yang diterima oleh Dinas Kesehatan Provinsi Sulawesi Selatan dari beberapa kabupaten yang menunjukkan kasus tertinggi yakni Kota Parepare, Kota Makassar, Kota Palopo, Kab. Enrekang dan Kab. Gowa. Menurut data program tahun 2008 tentang penyakit typhoid, tercatat 20.088 penderita dengan jumlah kematian sebanyak 3 orang [5]. 
Infeksi akibat bakteri ini dapat diobati dengan menggunakan antibiotik. Terdapat dua macam antibiotik yaitu sintetik dan alami. Antibiotik sintetik lebih populer dibandingkan alami namun, antibiotik sintesis juga membunuh bakteri menguntungkan yang ada dalam tubuh. Sekarang ini, antibiotik alami menjadi pilihan yang diperhitungkan untuk menggantikan antibiotik sintetik. Salah satu contoh antibiotik alami adalah minyak kelapa murni.

Minyak kelapa murni atau VCO (Virgin Coconut Oil) terkenal akan manfaatnya untuk kesehatan, seperti anti-bakteri, anti-virus, dan anti-fungi. Hal itu diduga disebabkan oleh kandungan asam lemak rantai sedang pada VCO. Krim yang mengandung $5-40 \%(w / w)$ VCO menunjukkan daya antibakteri terhadap bakteri Escherichia coli, Pseudomonas aeruginosa, Proteus vulgaris, dan Bacillus subtilis [6]. Emulsi monogliserida dari asam kaprat, monocaprin, dapat menurunkan viabilitas Salmonella spp. [7]. VCO mengandung asam kaprat, maka VCO berpotensi untuk memiliki daya antibakteri terhadap Salmonella. Namun, belum ada penelitian yang menguji daya antibakteri VCO terhadap Salmonella typhi. Oleh karena itu, penelitian ini bertujuan untuk mengetahui daya antibakteri VCO terhadap bakteri Salmonella typhi, sehingga diharapkan VCO dapat menjadi fitofarmaka untuk mengobati penyakit tipus.

\section{TINJAUAN PUSTAKA}

Kandungan bahan kimia VCO berbeda-beda tergantung varietas kelapa dan teknik pengolahan yang digunakan. Namun secara umum, kandungan asam lemak yang terdapat pada VCO ditunjukkan dalam Tabel 1.

Berdasarkan dari Tabel 1 VCO memiliki kandungan asam Laurat (Lauric acid) lebih besar atau sama dengan $45.1 \%$. Di dalam tubuh manusia, asam laurat diubah menjadi monolaurin. Monolaurin memiliki karakteristik anti-viral, antibakterial, dan anti-protozoal, sehingga dapat digunakan untuk melindungi emulsi minyak-dalamair yang ajak diinjeksikan secara intravenal dari pertumbuhan $E$. coli, $P$. aeruginaosa, Stahpylococcus aureus, dan Candida albicans [8]. Asam laurat bebas juga memiliki daya antibakteri, yaitu baik asam laurat maupun monolaurin memiliki daya antibakteri terhadap terhadap $S$. aureus [9]. Asam lemak rantai sedang dan turunannya seperti asam laurat dan monolaurin memiliki kemampuan menghancurkan bakteri yang memiliki selubung lipid dengan mengdisintegrasikan membran lipidnya. Kandungan asam lemak memberikan VCO daya anti-bakterial, anti-viral, dan anti-fungal. Selain itu VCO juga memiliki khasiat yang menyehatkan tubuh karena asam lemak yang terdapat di VCO mudah untuk diserap dan digunakan tubuh. VCO juga aman dikonsumsi karena bersifat natural, sehingga tidak mempunyai efek samping yang signifikan [10].

Tabel 1 Kandungan asam lemak VCO

\begin{tabular}{lcc}
\hline \multicolumn{1}{c}{ Nama umum } & Komposisi & $(\%)$ \\
\hline Caproic acid & C $6: 0$ & ND -0.7 \\
Caprylic acid & C $8: 0$ & $4.6-10.0$ \\
Capric acid & C 10:0 & $5.0-8.0$ \\
Lauric acid & C 12:0 & $\geq 45.1$ \\
Myristic acid & C 14:0 & $16.8-21.0$ \\
Palmitic acid & C $16: 0$ & $7.5-10.2$ \\
Palmitoleic acid & C $16: 1$ & ND* \\
Stearic acid & C $18: 0$ & $2.0-4.0$ \\
Oleic acid & C $18: 1$ & $5.0-10.0$ \\
Linoleic acid & C $18: 2$ & $1.0-2.5$ \\
& C $18: 3$ & ND -0.2 \\
Linolenic acid & C $24: 1$ & ND \\
\hline
\end{tabular}

*ND (Non-detecable) : Tidak dapat terdeteksi Sumber: Bawalan dan Chapman, 2006 [11]

S. typhi merupakan bakteri gram negatif bersifat aerobik atau anaerobik fakultatif, motil karena mempunyai flagel dengan tipe peritrik. S. typhi tidak berkapsul dan tidak membentuk spora. Selain itu $S$. typhi mempunyai antigen $V i$ kapsular selain antigenik somatik $(\mathrm{O})$ dan flagelar $(\mathrm{H})$ yang dapat digunakan untuk identifikasi serologis. Morfologi koloni $S$. typhi pada media agar padat adalah bulat, diameter 1-2 mm, tepi rata, ada titik gelap, elevasi cembung, konsistensi halus, dan warna jernih atau transparan. S. typhi dapat mengkolonisasi usus, dan melalui sistem limpatik, dibawa ke organ-organ lain (seperti hati, limpa, dan ginjal). Endotoksin yang dilepaskan oleh bakteri yang mati dapat menimbulkan gejala gangguan kesehatan, misalnya diare. 


\section{METODOLOGI PENELITIAN}

Penelitian dilaksanakan di Laboratorium Mikrobiologi Fakultas Sains dan Teknologi Universitas Al Azhar Indonesia. Waktu penelitian dimulai dari bulan Maret sampai Oktober 2011. Terdapat dua jenis metode yang digunakan dalam penelitian ini, yaitu metode kuantitatif dan kualitatif.

Kultur murni Salmonella typhi diperoleh dari Laboratorium Mikrobiologi Klinik Fakultas Kedokteran Universitas Indonesia. Kultur bakteri $S$. typhi disiapkan dengan cara menginokulasi bakteri ke dalam tabung reaksi berisi aquades steril. Tabung reaksi berisi kultur bakteri tersebut dihomogenisasi dengan stirrer selama 10 detik dan diinkubasi pada suhu $35^{\circ} \mathrm{C}$ selama 24 jam.

Metode penelitian kuantitatif menggunakan metode Kirby-Bauer untuk menghitung diameter zona hambat yang dibentuk oleh masing-masing zat uji yaitu VCO, Thiamphenicol, dan Ciprofloxacin. Setiap antibiotik perlu dilarutkan terlebih dahulu dengan perhitungan, $1 \mathrm{~g}$ antibiotik dilarutkan dalam air distilasi sampai volume larutan $10 \mathrm{~mL}$.

VCO yang digunakan adalah VCO yang telah siap pakai yang diperoleh dari PT Jayanusa Adimandiri. Pada metode ini, etanol $1 \%$ digunakan sebagai pelarut untuk membuat gradien konsentrasi VCO. Konsetrasi VCO yang digunakan adalah $20 \%(\mathrm{v} / \mathrm{v})$, $40 \%(\mathrm{v} / \mathrm{v}), 60 \%(\mathrm{v} / \mathrm{v}), 80 \%(\mathrm{v} / \mathrm{v})$ dan $100 \%(\mathrm{v} / \mathrm{v})$. Untuk kontrol negatif digunakan etanol $1 \%$ sebagai pembanding.

Pengujian dilakukan dengan metode disk-diffusion Kirby-Bauer untuk larutan VCO dan larutan antibiotik. Tiap cawan petri berisi media agar Müller-Hinton diberikan kultur bakteri dengan metode pour plate. Disk dicelupkan ke larutan yang akan diuji, yaitu kontrol negatif, VCO berbagai konsentrasi, dan antibiotik. Dua disk untuk masingmasing larutan. Disk yang dicelupkan pada larutan yang sama diletakkan di cawan yang sama. Pada Gambar 1 terlihat disk diletakkan tidak terlalu berdekatan kemudian diinkubasi pada suhu $35^{\circ} \mathrm{C}$ selama 24 jam.

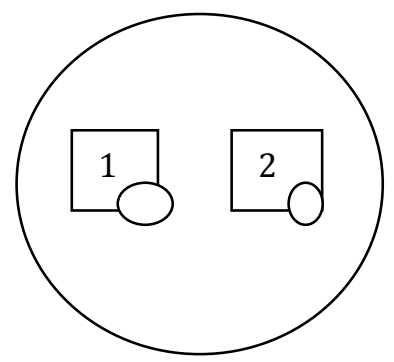

Gambar 1. Diagram peletakkan disk-diffusion.

Diameter zona hambat diukur dengan menggunakan penggaris sentimeter. Percobaan diulang sebanyak 2 kali untuk mendapatkan hasil yang reliable. Data yang diperoleh diolah menggunakan statistik deskriptif.

Metode penelitian kualitatif menggunakan metode pour plate dengan konsentrasi VCO $100 \%$. Terdapat dua perlakuan pada metode pour plate, perlakuan 1 kultur bakteri ditanam ke media Müeller-Hinton agar dengan metode pour plate. Setelah bakteri ditanam, $10 \mathrm{~mL}$ VCO langsung ditambahkan dengan metode pour plate dengan merata. Cawan petri diinkubasi pada suhu $35^{\circ} \mathrm{C}$ selama sekitar 24 jam.

Pada perlakuan 2, bakteri yang telah ditanam ke media Müeller-Hinton agar dengan metode pour plate diinkubasi pada suhu $35^{\circ} \mathrm{C}$ selama sekitar 24 jam terlebih dahulu kemudian sebanyak $10 \mathrm{~mL}$ VCO ditambahkan ke dalam media. Cawan petri kembali diinkubasi pada suhu $35^{\circ} \mathrm{C}$ selama sekitar 24 jam. Pengamatan dilakukan dengan melihat adatidaknya pertumbuhan bakteri yang ditunjukkan oleh tumbuhnya koloni. Percobaan diulang sebanyak 3 kali untuk mendapatkan hasil yang reliable. Data yang diperoleh diolah dengan menggunakan statistik deskriptif.

\section{HASIL DAN PEMBAHASAN}

Percobaan kuantitatif dengan menggunakan pelarut alkohol $1 \%$ menunjukkan hasil pengukuran ditampilkan dalam bentuk grafik batang seperti pada Gambar 2. 


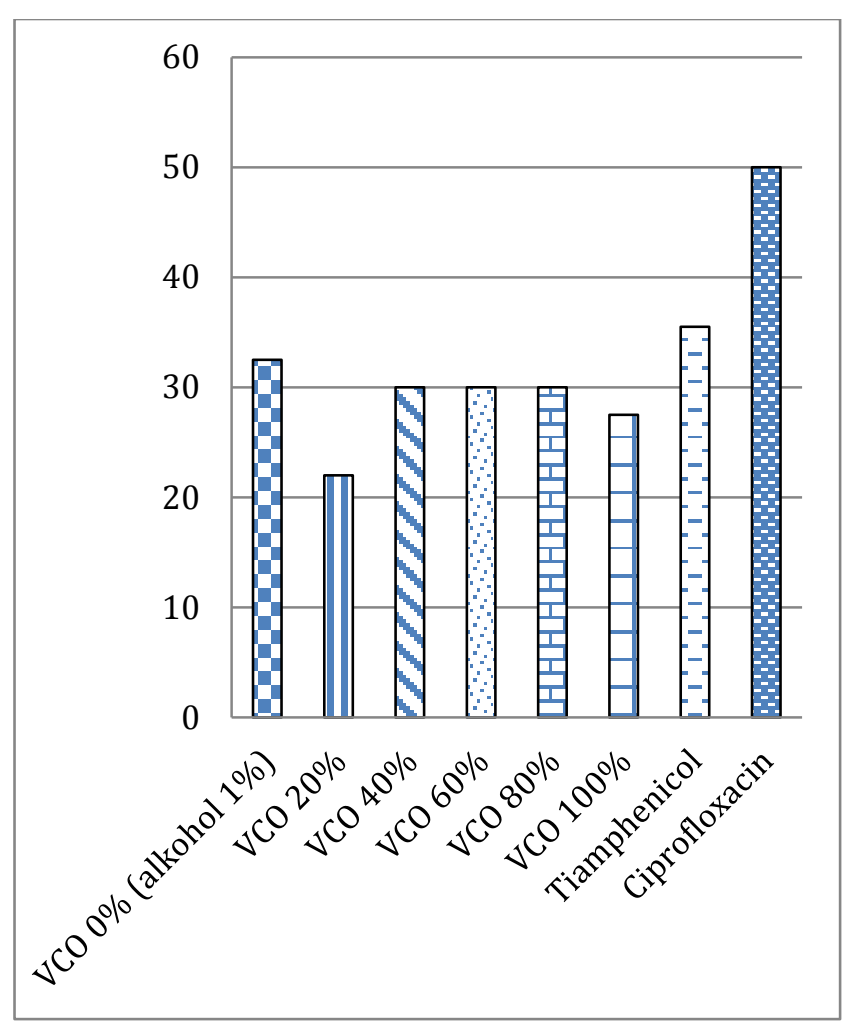

Gambar 2. Rata-rata zona hambat hasil pengujian kualitatif.

Pada percobaan kuantitatif, tampak adanya zona hambat di sekitar disk diffusion yang dicelupkan pada VCO. Pada gambar 2, konsentrasi VCO dimulai dari yang tertinggi hingga terendah adalah $40 \%$, 60\%, dan $80 \%$ sebesar $30 \mathrm{~mm}$, konsentrasi VCO 100\% $27.5 \mathrm{~mm}$, dan konsentrasi 20\% sebesar $22 \mathrm{~mm}$. Dengan demikian VCO mempunyai potensi sebagai anti-bakteri khususnya bakteri $S$. typhi. Hal ini disebabkan VCO mengandung asam Laurat dan asam Kaprat yang dapat bersifat sebagai anti-bakteri.

Nilai rata-rata zona hambat VCO $100 \%$ adalah $27.5 \mathrm{~mm}$, lebih kecil dari konsentrasi 40\%, 60\%, dan $80 \%$. Hal tersebut dapat disebabkan oleh besarnya molekul asam-asam lemak yang terdapat pada VCO, sehingga memperlambat difusinya pada media. Selain itu pelarut yang digunakan tampaknya juga kurang dapat melarutkan VCO ditunjukkan dengan masih terbentuknya emulsi. Hal tersebut disebabkan karena tidak menyatunya alkohol yang hidrofilik dengan asam-asam lemak yang bersifat hidrofobik. Pada kondisi ini zona hambat yang terbentuk kemungkinan akibat daya anti-bakteri alkohol.
Pada penelitian ini, pelarut yang digunakan belum dapat melarutkan VCO dengan baik. Karena VCO tidak terlarut dengan baik, maka terjadi bias terhadap jumlah VCO yang terlarut pada tiap cakram difusi. Selain itu, karena VCO tidak dapat terlarut dengan baik juga tidak dapat berdifusi dengan baik pada media. Kontrol negatif (alkohol 1\%) pada percobaan kuantitatif masih menunjukkan daya antibakterial, sehingga dikhawatirkan zona hambat yang terbentuk pada VCO dengan konsentrasi $20 \%-80 \%$ mendapat bias dari daya hambat alkohol $1 \%$.

Berdasarkan hasil penelitian daya hambat VCO terhadap $S$. typhi lebih kecil dibandingkan dengan Tiamphenicol dan Ciprofloxacin (Gambar 2.). Berdasarkan hasil pengamatan, terdapat perbedaan pada diameter zona hambat antibiotik dan VCO. Hal tersebut dapat disebabkan karena asam laurat tidak diubah menjadi monolaurin yang memiliki daya antibakteri lebih tinggi. Hal ini sesuai dengan penelitian sebelumnya yang menunjukkan bahwa konsentrasi baktersidial minimum asam laurat lebih rendah $(3.2 \mathrm{mg} / \mathrm{ml})$ dibandingkan monolaurin $(0.1$ $\mathrm{mg} / \mathrm{ml}$ ) terhadap Staphylococcus aureus [9].

Hasil pengamatan percobaan kuantitatif, perlakuan 1 , terlihat adanya pertumbuhan $S$. typhi. Setelah dilakukan 6 hari pengamatan, pertumbuhan bakteri S. typhi terhambat. Seperti yang terlihat pada Gambar 3. Pada gambar 3(a) adalah hasil pengamatan hari kedua. Dari hari kedua terlihat adanya pertumbuhan S. typhi. Hal ini dapat dilihat dari munculnya koloni bakteri di beberapa tempat pada agar.

Gambar 3(b) merupakan hasil pengamatan hari kelima. Hasil pengamatan pada hari kelima memperlihatkan bahwa jumlah koloni bakteri tidak mengalami pertambahan.

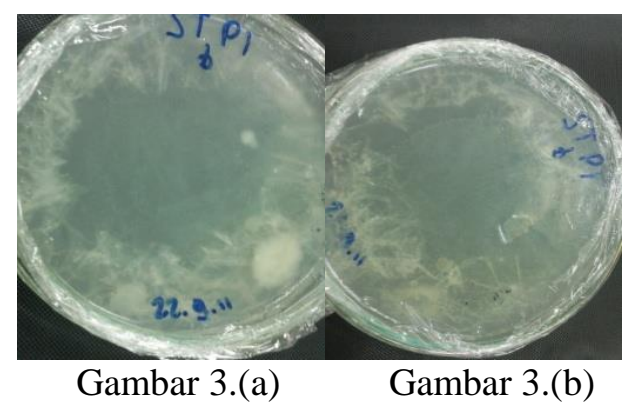

Gambar 3.Hasil pengamatan kultur bakteri S. typhi perlakuan pertamapada hari. (a) Pertama. (b)Kelima. 
Pada perlakuan 2, S. typhi tumbuh dengan bentuk koloni titik yang tersebar di hampir seluruh cawan. Setelah ditambahkan VCO pada kultur tersebut, pertumbuhan $S$. typhi menjadi terhambat. Hal ini terbukti karena tidak adanya pertumbuhan dan pertambahan jumlah koloni titik yang terdapat pada kultur. Seperti yang dapat dilihat pada gambar 5 .

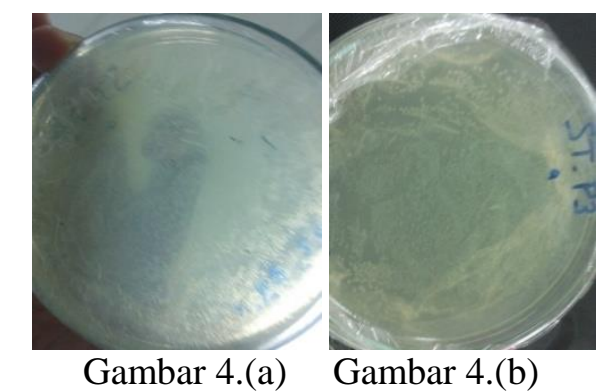

Gambar 4. Hasil pengamatan kultur bakteri S. typhi perlakuan kedua pada hari. (a) Pertama. (b) Kelima.

Hasil dari percobaan kualitatif yang diperoleh mendukung hasil dari percobaan kuantitatif yaitu VCO mempunyai daya anti-bakteri. Media yang ditambahkan VCO, baik langsung maupun setelah tumbuh, menunjukkan adanya hambatan dalam pertumbuhan bakteri. Dari studi literatur, diusulkan bahwa penghambatan pertumbuhan dapat dikarenakan oleh terganggunya permeabilitas membran sel bakteri oleh aktivitas deterjen asam lemak. Asam lemak akan mengganggu integrasi peptidoglikan pada dinding sel dengan berinkoperasi dengan dinding sel [12].

\section{KESIMPULAN}

Dari penelitian yang telah dilakukan, disimpulkan bahwa VCO mempunyai daya hambat terhadap pertumbuhan $S$. typhi secara in-vitro, sehingga berpotensi sebagai antibakteri $S$. typhi. Dalam pengujian selanjutnya, perlu digunakan pelarut yang lebih baik, seperti Tween.

\section{UCAPAN TERIMA KASIH}

Penelitian ini mendapat bantuan dana dari Lembaga Penelitian dan Pengembangan Masyarakat (LP2M) Universitas Al Azhar Indonesia pada tahun 2011.

\section{DAFTAR PUSTAKA}

[1] S. Sidabutar and H. I. Satari, "Pilihan terapi empiris demam tifoid pada anak: kloramfenikol atau seftriakson," sari pediatri, vol. 11, no. 6, p. 434, 2010.

[2] A. Rakhman, R. Humardewayanti and D. Pramono, "Faktor-faktor risiko yang berpengaruh terhadap kejadian demam tifoid pada orang dewasa," Berita Kedokteran Masyarakat, vol. 25, no. 4, pp. 167-175, 2009.

[3] D. K. Semarang, "Profil Kesehatan 2010," Dinas Kesehatan Semarang, Semarang, 2010.

[4] D. K. Semarang, "Profil Kesehatan 2011," Dinas Kesehatan Semarang, Semarang, 2011.

[5] Sudarianto, Mursalim, E. Parura, A. M. Nur, S. N. and I. Haruna, "Informasi Capaian Program Bidang Kesehatan di Sulawesi Selatan Tahun 2008," Dinas Kesehatan Provinsi Sulawesi Selatan, Makassar, 2009.

[6] A. R. Oyi, J. A. Onaolapo and R. C. Obi, "Formulation and antimicrobial studies of coconut (Cocos nucifera Linne) oil," Res. J. Appl. S. Eng. Tech., vol. 2, no. 2, pp. 133-137, 2010.

[7] H. Thomar, H. Hilmarsson and G. Bergsson, "Stable concentrated emulsions of the 1-monoglyceride of capric acid (monocaprin) with microbicidal activities against the foodborne bacteria Cmpylobacter jejuni, Sal;monella spp., and Escherichia coli," Appl. Environ. Microbiol, vol. 72, no. 1, pp. 522-526, 2006.

[8] G. v. Daftary, S. A. Pai and G. N. Shanbhag, "SStable emulsion compositions for intravenous administration having preservative efficacy". United States of America Patent 20080262084, 2008.

[9] P. Tangwatcharin and P. Khopaibool, "Activity of virgin coconut oil, lauric acid or monolaurin in combination with lactic acid against staphylococcus aureus," Southeast Asian J. Trop. Med. Public Health, vol. 43, no. 1, pp. 969-985, 2012.

[10] M. G. Enig, "Coconut: in support of good health in the 21st century," [Online]. Available: http://coconutoil.com/coconut_oil_21st_century/. [Accessed 14 Februari 2011].

[11] D. D. Bawalan and K. R. Chapman, Virgin Coconut Oil production manual for micro- and village-scale processing, Bangkok: FAO Regional Office for Asia and the Pacific, 2006.

[12] G. Bergsson, J. Arnfinnsson, O. Steingrimsson and H. Thormar, "In vitro killing of candida albicans by fatty acids and monoglycerides," Antimicrobial Agents and Chemoteraphy, vol. 45, no. 11, pp. 32093212, 2001. 